\title{
Sphingomonas changbaiensis sp. nov., isolated from forest soil
}

Correspondence

Shuang-Jiang Liu

liusj@sun.im.ac.cn
Jia-Yue Zhang, ${ }^{1}$ Xing-Yu Liu ${ }^{1,2}$ and Shuang-Jiang Liu ${ }^{1}$

\author{
${ }^{1}$ State Key Laboratory of Microbial Resources, Institute of Microbiology, Chinese Academy of \\ Sciences, Beijing, 100101, PR China \\ ${ }^{2}$ National Engineering Laboratory of Biohydrometallurgy, General Research Institute for Nonferrous \\ Metals, Beijing, 100088, PR China
}

The genus Sphingomonas was proposed by Yabuuchi et al. (1990) and has been subsequently emended by Takeuchi et al. (2001), Yabuuchi et al. (2002) and Busse et al. (2003). On the basis of phylogenetic analysis of 16S rRNA gene sequences, polyamine patterns and polar lipid profiles, Takeuchi et al. (2001) proposed that the genus Sphingomonas should be classified into four genera Sphingomonas, Novosphingobium, Sphingobium and Sphingopyxis, however, the phenotypic evidence to support this proposal was weak (Yabuuchi et al., 2002). According to Busse et al. (2003), species of the genus Sphingomonas comprising cluster I as proposed by Takeuchi et al. (2001), with sym-homospermidine as the major polyamine pattern, should be considered as members of Sphingomonas sensu stricto, with Sphingomonas paucimobilis as the type species. Members of this genus are off-white, yellow or orange-pigmented, non-fermentative, Gram-negative, non-motile or motile rods with a single polar

The GenBank/EMBL/DDBJ accession number for the 16S rRNA gene sequence of strain $\mathrm{V} 2 \mathrm{M} 44^{\top}$ is EU682685.

Figures showing additional phylogenetic trees, scanning and transmission electron micrographs of cells of strain $\mathrm{V} 2 \mathrm{M} 44^{\top}$ and the results of the polar lipid analysis are available as supplementary figures. A supplementary table detailing the cellular fatty acid contents of strain $\mathrm{V} 2 \mathrm{M} 44^{\top}$ is also available with the online version of this paper. flagellum or peritrichous flagella and are characterized by the presence of sym-homospermidine, a unique sphingoglycolipid, Q-10, 2-hydroxymyristic acid and the absence of 3hydroxy fatty acids. In this study, we report the isolation and identification of a novel isolate, strain $\mathrm{V} 2 \mathrm{M} 44^{\mathrm{T}}$, from a sample of forest soil.

In an attempt to study the cultured microbial diversity in forest soil from the Changbai Mountains, Heilongjiang Province, China, bacterial strains were isolated by using a serial dilution method (Sait et al., 2002). V2M isolation medium was modified from VL55 medium (Sait et al., 2002) by the addition of $\left(1^{-1}\right): 5 \mathrm{ml}$ amino acid mixture (Davis et al., 2005), $1 \mathrm{ml}$ vitamin solution 1 (Janssen et al., 1997), $3 \mathrm{ml}$ vitamin solution 2 (Janssen et al., 1997), $100 \mu \mathrm{l}$ solution 1 and $5 \mathrm{ml}$ solution 2. Gellan (1.5\%) was used as the solidifying agent. Solution 1 contained the following ingredients $\left(\mathrm{l}^{-1}\right): 4 \mathrm{mg} \mathrm{SrCl} 2,3 \mathrm{mg} \mathrm{NaSiO}{ }_{3} .9 \mathrm{H}_{2} \mathrm{O}, 3 \mathrm{mg}$ $\mathrm{TiO}_{2}, 2 \mathrm{mg} \mathrm{Cd}\left(\mathrm{NO}_{3}\right)_{2} \cdot 4 \mathrm{H}_{2} \mathrm{O}$ and $2 \mathrm{mg} \mathrm{SnCl}_{2} \cdot \mathrm{H}_{2} \mathrm{O}$. Solution 2 contained $\left(1^{-1}\right): 30 \mathrm{mg}$ DL-glyceraldehyde, $20 \mathrm{mg}$ chromotropic acid, $70 \mathrm{mg}$ gallic acid, $30 \mathrm{mg}$ ascorbic acid, $10 \mathrm{mg}$ sodium thioglycolate, $50 \mathrm{mg}$ sodium succinate, $50 \mathrm{mg}$ DL-malic acid, $50 \mathrm{mg}$ saligenin, $50 \mathrm{mg}$ sorbitol, $40 \mathrm{mg}$ salicin, $20 \mathrm{mg}$ barbital, $20 \mathrm{mg}$ aconitic acid, $30 \mathrm{mg}$ creatine and $30 \mathrm{mg}$ sodium deoxycholate. 
Strain V2M44 ${ }^{\mathrm{T}}$ was isolated from several V2M plates inoculated with the $10^{-7}$ dilution after one week of incubation at $30^{\circ} \mathrm{C}$. Each plate displayed several tiny yellow colonies of strain V2M44 ${ }^{\mathrm{T}}$.

The nearly complete $16 \mathrm{~S}$ rRNA gene of strain V2M44 ${ }^{\mathrm{T}}$ (1477 bp) was amplified and sequenced according to the method described by Zhang et al. (2003). DNA BLAST searches (Altschul et al., 1990) of 16S rRNA gene similarity using the NCBI database showed that strain V2M $44^{\mathrm{T}}$ was phylogenetically related to members of the genus Sphingomonas. Alignments of the $16 \mathrm{~S}$ rRNA gene sequences of members of the genus Sphingomonas were performed with the CLUSTAL_X program (version 1.64b, Thompson et al., 1997) and the alignment positions with insertions or deletions were excluded from calculations. Phylogenetic trees based on 16S rRNA gene sequence analysis were constructed by the neighbour-joining and maximumparsimony methods with Kimura's two-parameter calculation model in MEGA version 3.1 (Kumar et al., 2004), and by the maximum-likelihood method in fastDNAml version 1.2.2 (Olsen et al., 1994; Felsenstein, 1981). 16S rRNA gene sequence analysis indicated that strain $\mathrm{V} 2 \mathrm{M} 44^{\mathrm{T}}$ was phylogenetically related to members of the genus Sphingomonas, with sequence similarities ranging from 92.0 to $95.8 \%$. In particular, strain $\mathrm{V} 2 \mathrm{M} 44^{\mathrm{T}}$ was closely related to Sphingomonas mali NBRC $15500^{\mathrm{T}}(95.8 \%)$, Sphingomonas kaistensis $\mathrm{PB}^{\mathrm{T}}{ }^{\mathrm{T}}(95.8 \%)$, Sphingomonas oligophenolica S213 ${ }^{\mathrm{T}}(95.8 \%)$, Sphingomonas dokdonensis DS-4 ${ }^{\mathrm{T}}(95.6 \%)$, Sphingomonas pituitosa EDIV $^{\mathrm{T}}(95.6 \%)$, Sphingomonas pruni NBRC $15498^{\mathrm{T}}$ (95.6\%), Sphingomonas aerolata $\mathrm{NW}^{2} 2^{\mathrm{T}}(95.4 \%)$, Sphingomonas asaccharolytica NBRC $15499^{\mathrm{T}}(95.3 \%)$, Sphingomonas azotifigens $\mathrm{Y}^{\mathrm{T}}{ }^{\mathrm{T}}$ (95.3\%), Sphingomonas trueperi ATCC $12417^{\mathrm{T}}$ (95.3\%), Sphingomonas desiccabilis $\mathrm{CP}^{\mathrm{T}} \mathrm{D}^{\mathrm{T}}(95.2 \%)$, Sphingomonas molluscorum KMM $3882^{\mathrm{T}}(95.2 \%)$, Sphingomonas echinoides DSM $1805^{\mathrm{T}}(95.1 \%)$, Sphingomonas astaxanthinifaciens TDMA- $17^{\mathrm{T}}(95.1 \%)$, Sphingomonas aquatilis $\mathrm{JSS}^{\mathrm{T}}$ $(95.0 \%)$, and Sphingomonas koreensis JSS26 $^{\mathrm{T}}(95.0 \%)$. The phylogenetic tree (Fig. 1) also indicated that strain V2M44 ${ }^{\mathrm{T}}$ clustered with species of the genus Sphingomonas and the topologies of the maximum-parsimony tree and maximum-likelihood tree were essentially the same (see Supplementary Figs S1 and S2 in IJSEM Online).

The morphological, physiological and biochemical characteristics of strain $\mathrm{V} 2 \mathrm{M} 44^{\mathrm{T}}$ were investigated using routine cultivation on diluted tryptic soy broth (D-TSB) medium at $30{ }^{\circ} \mathrm{C}$. The D-TSB medium was $1 / 5$ strength tryptic soy broth agar and contained $0.6 \mathrm{~g}$ of Bacto tryptic soy broth dissolved in $100 \mathrm{ml}$ water. Growth was also assessed in tryptic soy broth (TSB), 1/2, 1/10 and $1 / 20$ strength TSB, as well as in Luria-Bertani broth (LB), 1/10 strength LB, nutrient broth (NB, Yabuuchi et al., 2002) and $1 / 2$ strength NB. NB contained $0.5 \mathrm{~g}$ Bacto peptone and $0.3 \mathrm{~g}$ Bacto yeast extract in $100 \mathrm{ml}$ water. The Gram stain was performed according to Gerhardt et al. (1994) with cells grown on D-TSB agar at $30{ }^{\circ} \mathrm{C}$ for 3 days. Morphological observations were performed by transmission (H-600; Hitachi) and scanning
(Quanta 200; FEI) electron microscopy. The presence of flagella, gliding motility and growth under anaerobic conditions were examined according to Dong \& Cai (2001). The growth temperature range was determined with a TN3F temperature gradient incubator (Advantec) at 12, 13, $14,16,17.5,19,21,22,24,27,28,29,31,34,36,38,41,45,49$, 51 and $56{ }^{\circ} \mathrm{C}$. The $\mathrm{pH}$ range for growth was tested at $\mathrm{pH} 4.0$, 5.0, 5.5, 6.0, 6.5, 7.0, 7.5, 8.0, 8.5, 9.1 and 9.8 by using D-TSB in which the $\mathrm{pH}$ was adjusted by the addition of $5 \mathrm{M} \mathrm{NaOH}$ or $\mathrm{HCl}$ and verified after autoclaving. Tolerance to $\mathrm{NaCl}$ was examined in D-TSB supplemented with $0,0.05,0.1,0.2,0.3$, $0.4,0.5,1.0$ and $2.0 \%(\mathrm{w} / \mathrm{v}) \mathrm{NaCl}$. Tests for catalase and oxidase activities and for the hydrolysis of casein, starch, Tween 20 and Tween 80 were performed according to Dong \& Cai (2001). In addition, strain V2M44 ${ }^{\mathrm{T}}$ was characterized by using API 20NE, API $50 \mathrm{CH}$ and API ZYM identification systems (bioMérieux) at $30{ }^{\circ} \mathrm{C}$.

Cells of strain V2M44 $4^{\mathrm{T}}$ were Gram-negative, rod-shaped and $0.3-0.4 \mu \mathrm{m}$ in diameter and $1.5-2.5 \mu \mathrm{m}$ in length. Cells were strictly aerobic and were motile by means of peritrichous flagella (see Supplementary Fig. S3 in IJSEM Online). Detailed physiological and biochemical characteristics of strain $\mathrm{V} 2 \mathrm{M} 44^{\mathrm{T}}$ are presented in the species description and the properties that distinguish the novel strain from closely related species are listed in Table 1.

The cell mass of strain V2M44 ${ }^{\mathrm{T}}$ and S. mali JCM $10193^{\mathrm{T}}$ used for chemotaxonomic analyses was produced on D-TSB agar at $30{ }^{\circ} \mathrm{C}$ for 3 days. Cellular fatty acids were extracted, methylated and analysed by the Sherlock Microbial Identification System following the manufacturer's instructions. Isoprenoid quinones were extracted and purified according to the method of Collins (1985) and analysed by HPLC (Wu et al., 1989; Hu et al., 2004). Polyamines were analysed as described previously (Flores \& Galston, 1982), with strain S. mali JCM $10193^{\mathrm{T}}$ (Takeuchi et al., 1995) as the reference strain in a parallel experiment. Polar lipids were extracted according to the modified method of Kamekura (1993) and separated by TLC on Merck Kieselgel 60-HPTLC by two-dimensional development as described by Ross et al. (1985). Phospholipids were detected with the Zinzadze reagent of Dittmer \& Lester (1964). Glycolipids were detected by spraying the plate with $0.5 \% 1$-naphthol in methanol/water $(1: 1 \mathrm{v} / \mathrm{v})$ and then with sulfuric acid/ ethanol $(1: 1 \mathrm{v} / \mathrm{v})$, followed by heating at $120{ }^{\circ} \mathrm{C}$ for $5-$ $10 \mathrm{~min}$ (Xin et al., 2001). Whole lipid profiles were detected by spraying with molybdatophosphoric acid (10 g molybdatophosphoric acid hydrate in $100 \mathrm{ml}$ ethanol) followed by heating at $120-160{ }^{\circ} \mathrm{C}$ (Worliczek et al., 2007).

The predominant isoprenoid quinone of strain $\mathrm{V} 2 \mathrm{M} 44^{\mathrm{T}}$ was ubiquinone-10 (Q-10). The fatty acid profile of strain V2M $44^{\mathrm{T}}$ comprised $\mathrm{C}_{17: 1} \omega 6 c(38.9 \%)$, summed feature 7 (comprising $\mathrm{C}_{18: 1} \omega 7 \mathrm{c}, \quad \mathrm{C}_{18: 1} \omega 9 t$ and/or $\mathrm{C}_{18: 1} \omega 12 t$, $31.5 \%), \mathrm{C}_{16: 0}(5.3 \%)$ and $\mathrm{C}_{17: 1} \omega 8 c(5.2 \%)$. The hydroxy fatty acids were $\mathrm{C}_{15: 0} 2-\mathrm{OH}(4.4 \%), \mathrm{C}_{16: 0} 2-\mathrm{OH}(1.8 \%)$ and $\mathrm{C}_{14: 0} 2-\mathrm{OH}(1.3 \%)$. No 3-hydroxy fatty acids were detected in this strain. The fatty acid composition of the 


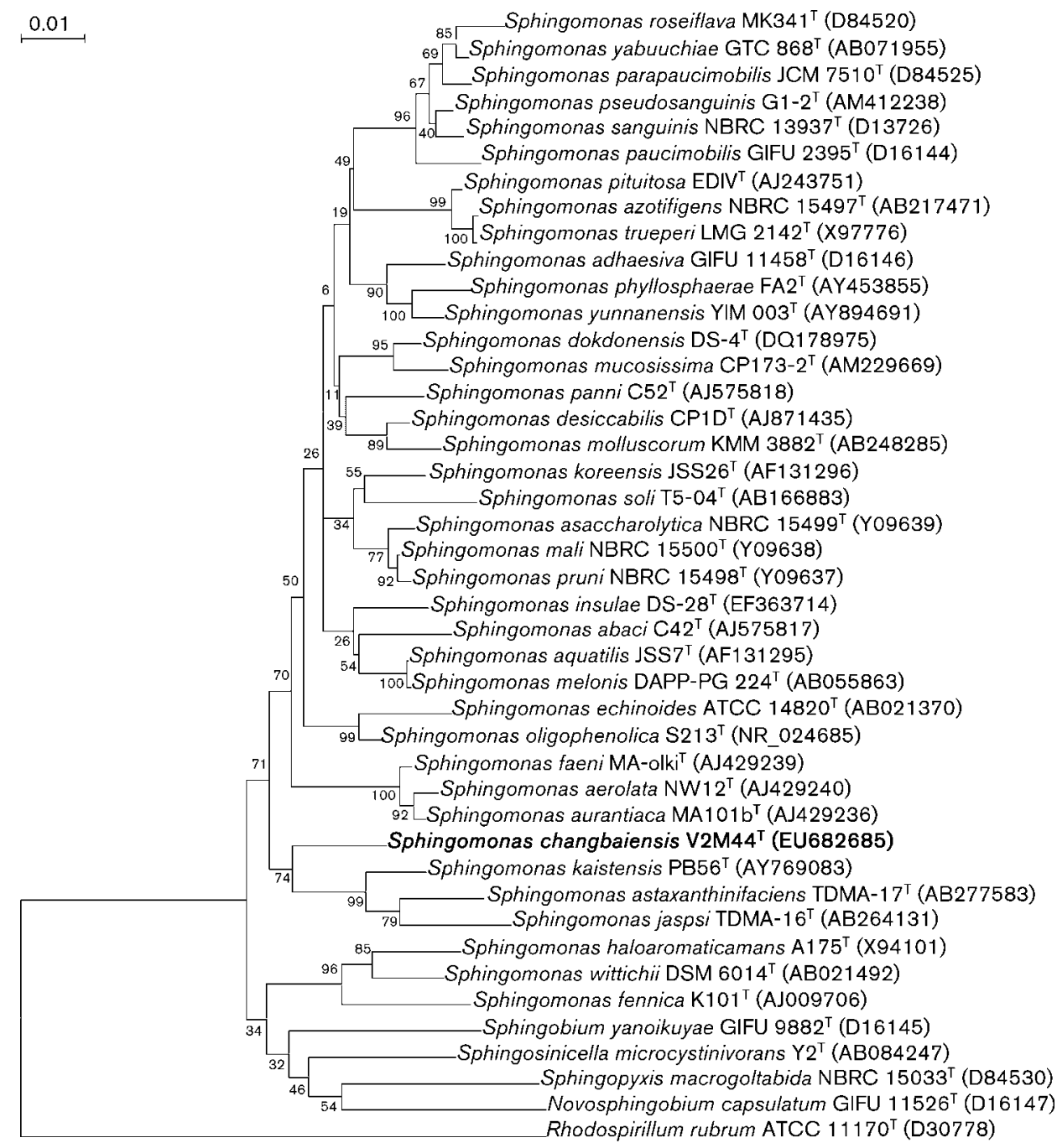

Fig. 1. Phylogenetic tree constructed with the neighbour-joining method according to the $16 S$ rRNA gene evolutionary distance between strain $\mathrm{V} 2 \mathrm{M} 44^{\top}$ and the type strains of the genera Sphingomonas, Sphingobium, Sphingopyxis, Sphingosinicella and Novosphingobium. The topology shows that strain V2M44 ${ }^{\top}$ and other species of the genus Sphingomonas are clustered together. Rhodospirillum rubrum ATCC $11170^{\top}$ was used as the outgroup. GenBank accession numbers are given in parentheses. The numbers at the nodes represent the confidence levels from bootstrap sampling (100 replicates). Bar, 0.01 evolutionary distance $\left(K_{\text {nuc }}\right)$.

strain $\mathrm{V} 2 \mathrm{M} 44^{\mathrm{T}}$ is given in more detail in Supplementary Table S1 (available in IJSEM Online). The major polyamine was sym-homospermidine. The major polar lipids were sphingoglycolipid, phosphatidylmonomethylethanolamine, phosphatidylethanolamine, phosphatidylglycerol, diphosphatidylglycerol, two unidentified phospholipids and four unidentified glycolipids (see Supplementary Fig. S4). Phosphatidyldimethylethanolamine and phosphatidylcholine were not detected, distinguishing strain $\mathrm{V} 2 \mathrm{M} 44^{\mathrm{T}}$ from $S$. pituitosa, S. pruni, S. asaccharolytica and S. trueperi (Denner et al., 2001; Kämpfer et al., 1997). The chemotaxonomic features of strain $\mathrm{V} 2 \mathrm{M} 44^{\mathrm{T}}$, including $\mathrm{Q}-10$ as the major isoprenoid quinone, $\mathrm{C}_{17: 1} \omega 6 c$ and summed feature 7 as the major fatty acids, the absence of 3-hydroxy fatty acids and the presence of sphingoglycolipid are as expected for species closely related to the genus Sphingomonas (Busse et al., 2003; Denner et al., 1999, 2001; Kämpfer et al., 1997; Lee et al., 2001; Reddy \& Garcia-Pichel, 2007; Romanenko et al., 2007; Takeuchi et al., 1995; Xie \& Yokota, 2006; Yoon et al., 2006).

The DNA base composition was determined by thermal denaturation (Marmur \& Doty, 1962) and Escherichia coli $\mathrm{K}-12^{\mathrm{T}}$ was used as the reference. The DNA G $+\mathrm{C}$ content of strain $\mathrm{V} 2 \mathrm{M} 44^{\mathrm{T}}$ was $65.8 \%\left(T_{\mathrm{m}}\right)$, which is within the range of values (60.7-69.9\%) previously reported for the genus Sphingomonas.

Based on the above phenotypic and phylogenetic studies, it is clear that strain $\mathrm{V} 2 \mathrm{M} 44^{\mathrm{T}}$ is a member of the genus 
Table 1. Phenotypic characteristics that differentiate strain $\mathrm{V} 2 \mathrm{M} 44^{\top}$ from related members of the genus Sphingomonas

Taxa: 1, V2M44 ${ }^{\mathrm{T}}$; 2, S. mali NBRC $15500^{\mathrm{T}}$ (data from Takeuchi et al., 1995); 3, S. kaistensis $\mathrm{PB}^{\mathrm{T}}{ }^{\mathrm{T}}$ (Kim et al., 2007); 4, S. oligophenolica S213 ${ }^{\mathrm{T}}$ (Ohta et al., 2004); 5, S. dokdonensis DS-4 ${ }^{\mathrm{T}}$ (Yoon et al., 2006); 6, S. pituitosa $\mathrm{EDIV}^{\mathrm{T}}$ (Denner et al., 2001); 7, S. pruni NBRC $15498^{\mathrm{T}}$ (Takeuchi et al., 1995); 8, S. aerolata NW12 ${ }^{\mathrm{T}}$ (Busse et al., 2003); 9, S. asaccharolytica NBRC $15499^{\mathrm{T}}$ (Takeuchi et al., 1995); 10, S. azotifigens $\mathrm{Y}^{\mathrm{T}} 9^{\mathrm{T}}$ (Xie \& Yokota, 2006); 11, S. trueperi ATCC $12417^{\mathrm{T}}$ (Kämpfer et al., 1997); 12, S. desiccabilis CP1D ${ }^{\mathrm{T}}$ (Reddy \& Garcia-Pichel, 2007); 13, S. molluscorum KMM 3882 ${ }^{\mathrm{T}}$ (Romanenko et al., 2007); 14, S. echinoides DSM $1805^{\mathrm{T}}$ (Denner et al., 1999); 15, S. astaxanthinifaciens TDMA-17 ${ }^{\mathrm{T}}$ (Asker et al., 2007); 16, S. aquatilis $\mathrm{JSS7}^{\mathrm{T}}$ (Lee et al., 2001); 17, S. koreensis $\mathrm{JSS}^{2} 6^{\mathrm{T}}$ (Lee et al., 2001). All strains are negative for indole production and arginine dihydrolase activity; all strains are positive for catalase activity. +, Positive; -, negative; $(+)$, weakly positive; ND, not determined or no data; Y, yellow; LY, light yellow; DY, dark yellow; O, orange; OR, orange red; PY, pale yellow.

\begin{tabular}{|c|c|c|c|c|c|c|c|c|c|c|c|c|c|c|c|c|c|}
\hline Characteristic & 1 & 2 & 3 & 4 & 5 & 6 & 7 & 8 & 9 & 10 & 11 & 12 & 13 & 14 & 15 & 16 & 17 \\
\hline Colony colour & Y & LY & OR & PY & Y & DY & LY & $\mathrm{O}$ & LY & Y & Y & Y & Y & Y & DY & $\mathrm{Y}$ & Y \\
\hline Motility & + & + & - & - & + & + & + & + & + & + & + & - & - & + & + & + & + \\
\hline Nitrate reduction & - & - & - & + & - & - & - & - & - & - & ND & + & + & ND & - & - & - \\
\hline Urease activity & + & - & - & - & - & - & - & - & - & ND & - & - & - & - & - & - & - \\
\hline Gelatin hydrolysis & + & - & - & + & + & - & - & - & - & - & + & + & - & - & + & - & - \\
\hline$\beta$-Galactosidase & - & + & - & ND & - & + & + & - & + & $\mathrm{ND}$ & + & + & + & + & - & + & + \\
\hline \multicolumn{18}{|l|}{ Assimilation of: } \\
\hline $\begin{array}{l}N \text {-Acetyl-D- } \\
\text { glucosamine }\end{array}$ & - & + & + & ND & - & + & + & + & + & $\mathrm{ND}$ & + & ND & + & + & - & + & + \\
\hline Adipate & + & + & + & ND & + & - & - & $(+)$ & - & - & - & $\mathrm{ND}$ & - & - & - & - & - \\
\hline L-Arabinose & - & $(+)$ & - & + & - & + & + & + & $(+)$ & + & + & + & + & + & - & + & - \\
\hline Malate & $(+)$ & - & + & - & - & + & + & + & - & + & + & $\mathrm{ND}$ & - & + & - & - & + \\
\hline Maltose & - & - & + & + & - & + & + & + & + & + & + & + & + & $(+)$ & - & + & + \\
\hline D-Mannitol & - & - & + & ND & - & - & - & - & - & $\mathrm{ND}$ & - & - & - & - & - & - & - \\
\hline D-Mannose & - & + & + & + & + & + & + & + & $(+)$ & ND & + & + & + & - & - & - & - \\
\hline Phenylacetate & - & ND & - & - & - & - & - & - & $\mathrm{ND}$ & ND & - & ND & - & - & - & - & - \\
\hline $\begin{array}{l}\text { DNA G+C content } \\
\quad(\mathrm{mol} \%)\end{array}$ & 65.8 & $\begin{array}{r}65.4- \\
65.9\end{array}$ & 69.9 & 64.2 & 66.9 & 64.5 & 65.4 & 65.4 & 64.8 & 68.0 & 65.6 & ND & 68.3 & 65.8 & 63.3 & 63.0 & 66.0 \\
\hline
\end{tabular}

Sphingomonas. Strain $\mathrm{V} 2 \mathrm{M} 44^{\mathrm{T}}$ exhibited a range of phenotypic characteristics that differentiated it from the currently recognized species of the genus Sphingomonas (Table 1), such as urease and $\beta$-galactosidase activities, assimilation of various carbon sources and the polar lipid profile. Therefore, it is concluded that strain $\mathrm{V} 2 \mathrm{M} 44^{\mathrm{T}}$ represents a novel species of the genus Sphingomonas for which the name of Sphingomonas changbaiensis sp. nov. is proposed.

\section{Description of Sphingomonas changbaiensis sp. nov.}

Sphingomonas changbaiensis (chang.bai.en'sis. N.L. fem. adj. changbaiensis pertaining to the Changbai mountains, in the north-east of China, from where the type strain was isolated).

Strictly aerobic, Gram-negative, heterotrophic, oxidase- and catalase-positive. Cells are rods of $0.3-0.4 \mu \mathrm{m}$ in diameter and $1.5-2.5 \mu \mathrm{m}$ in length and are motile by means of peritrichous flagella. Colonies on D-TSB agar are circular, entire and yellow. No growth is detected on TSB agar, 1/2 strength TSB agar, LB agar, 1/10 strength LB agar, NB agar or $1 / 2$ strength NB agar. Growth occurs on $1 / 5$ and $1 / 10$ strength TSB agar. Growth occurs at $20-33{ }^{\circ} \mathrm{C}$ (optimum, 29-31 ${ }^{\circ} \mathrm{C}$ ), at $\mathrm{pH} 5-8$ (optimum, $\mathrm{pH}$ 6.0-7.0) and in the presence of $0-0.1 \%(\mathrm{w} / \mathrm{v}) \mathrm{NaCl}$ (optimum, $0.05 \%$ ). Nitrate is not reduced. Gelatin, aesculin, Tween 20 and Tween 80 are hydrolysed, but casein and starch are not hydrolysed. Urease activity is present, but arginine dihydrolase activity is absent. Indole and $\mathrm{H}_{2} \mathrm{~S}$ are not produced. Assimilates D-glucose, gluconate, adipate and malate, but not the following compounds: D-mannitol, maltose, L-arabinose, D-mannose, $\mathrm{N}$-acetyl-D-glucosamine, caprate, citrate and phenylacetate. In the API $50 \mathrm{CH}$ test system, acids are produced from glycerol, D-fructose, $N$-acetylglucosamine, aesculin and ferric citrate. All other API $50 \mathrm{CH}$ test results are negative. In the API ZYM test system, alkaline phosphatase, esterase, lipase (C8), leucine arylamidase, valine arylamidase, cystine arylamidase, $\alpha$-chymotrypsin, acid phosphatase and naphthol-AS-BI-phosphohydrolase activities are present. Esterase (C4), lipase (C14), trypsin, $N$-acetyl- $\beta$-glucosami- 
nidase, $\alpha$-galactosidase, $\beta$-galactosidase, $\beta$-glucuronidase, $\beta$-glucosidase, $\alpha$-glucosidase, $\alpha$-mannosidase and $\alpha$-fucosidase activities are absent. The predominant cellular fatty acids are $\mathrm{C}_{17: 1} \omega 6 c$, summed feature 7 (comprising $\mathrm{C}_{18: 1} \omega 7 c$, $\mathrm{C}_{18: 1} \omega 9 t$ and/or $\left.\mathrm{C}_{18: 1} \omega 12 t\right), \mathrm{C}_{16: 0}, \mathrm{C}_{17: 1} \omega 8 c$ and $\mathrm{C}_{15: 0}$ 2-OH. The major isoprenoid quinone is $\mathrm{Q}-10$. The major polyamine is $s y m$-homospermidine. The major polar lipids are sphingoglycolipid, phosphatidylethanolamine and phosphatidylglycerol.

The type strain, V2M $44^{\mathrm{T}}\left(=\mathrm{CGMCC} 1.7057^{\mathrm{T}}=\mathrm{NBRC}\right.$ $\left.104936^{\mathrm{T}}\right)$, was isolated from forest soil. The DNA G+C content of the type strain is $65.8 \mathrm{~mol} \%\left(T_{\mathrm{m}}\right)$.

\section{Acknowledgements}

This work was supported by grants from the National Nature Science Foundation of China (30725001) and the Chinese Academy of Sciences (KSCX2-YW-G-052).

\section{References}

Altschul, S. F., Gish, W., Miller, W., Myers, E. W. \& Lipman, D. J. (1990). Basic local alignment search tool. J Mol Biol 215, 403-410.

Asker, D., Beppu, T. \& Ueda, K. (2007). Sphingomonas astaxanthinifaciens sp. nov., a novel astaxanthin-producing bacterium of the family Sphingomonadaceae isolated from Misasa, Tottori, Japan. FEMS Microbiol Lett 273, 140-148.

Busse, H. J., Denner, E. B., Buczolits, S., Salkinoja-Salonen, M., Bennasar, A. \& Kämpfer, P. (2003). Sphingomonas aurantiaca sp. nov., Sphingomonas aerolata sp. nov. and Sphingomonas faeni sp. nov., air- and dustborne and Antarctic, orange-pigmented, psychrotolerant bacteria, and emended description of the genus Sphingomonas. Int J Syst Evol Microbiol 53, 1253-1260.

Collins, M. D. (1985). Isoprenoid quinone analysis in classification and identification. In Chemical Methods in Bacterial Systematics, pp. 267-287. Edited by M. Goodfellow \& D. E. Minnikin. London: Academic Press.

Davis, K. E., Joseph, S. J. \& Janssen, P. H. (2005). Effects of growth medium, inoculum size, and incubation time on culturability and isolation of soil bacteria. Appl Environ Microbiol 71, 826-834.

Denner, E. B., Kämpfer, P., Busse, H. J. \& Moore, E. R. (1999). Reclassification of Pseudomonas echinoides Heumann 1962, 343 ${ }^{\mathrm{AL}}$, in the genus Sphingomonas as Sphingomonas echinoides comb. nov. Int $J$ Syst Bacteriol 49, 1103-1109.

Denner, E. B., Paukner, S., Kämpfer, P., Moore, E. R., Abraham, W. R., Busse, H. J., Wanner, G. \& Lubitz, W. (2001). Sphingomonas pituitosa sp. nov., an exopolysaccharide-producing bacterium that secretes an unusual type of sphingan. Int J Syst Evol Microbiol 51, 827-884.

Dittmer, J. C. \& Lester, R. L. (1964). A simple, specific spray for the detection of phospholipids on thin-layer chromatograms. J Lipid Res $15,126-127$.

Dong, X.-Z. \& Cai, M.-Y. (editors) (2001). Determination of biochemical properties. In Manual for the Systematic Identification of General Bacteria, pp. 370-398. Beijing: Science Press (in Chinese).

Felsenstein, J. (1981). Evolutionary trees from DNA sequences: A maximum likelihood approach. J Mol Evol 17, 368-376.

Flores, H. E. \& Galston, A. W. (1982). Analysis of polyamines in higher plants by high performance liquid chromatography. Plant Physiol 69, 701-706.
Gerhardt, P., Murray, R. G. E., Wood, W. A. \& Krieg, N. R. (editors) (1994). Methods for General and Molecular Bacteriology. Washington, DC: American Society for Microbiology.

Hu, Y. T., Zhou, P. J., Zhou, Y. G., Liu, Z. H. \& Liu, S. J. (2004). Saccharothrix xingjiangensis, sp. nov., a pyrene-degrading actinomycete isolated from Tianchi Lake, Xinjiang, China. Int J Syst Evol Microbiol 54, 2091-2094.

Janssen, P. H., Schuhmann, A., Morschel, E. \& Rainey, F. A. (1997). Novel anaerobic ultramicrobacteria belonging to the Verrucomicrobiales lineage of bacterial descent isolated by dilution culture from anoxic rice paddy soil. Appl Environ Microbiol 63, 1382-1388.

Kamekura, M. (1993). Lipids of extreme halophiles. In The Biology of Halophilic Bacteria, pp. 135-161. Edited by R. H. Vreeland \& L. I. Hochstein. Boca Raton, FL: CRC Press.

Kämpfer, P., Denner, E. B., Meyer, S., Moore, E. R. \& Busse, H. J. (1997). Classification of "Pseudomonas azotocolligans" Anderson 1955, 132, in the genus Sphingomonas as Sphingomonas trueperi sp. nov. Int J Syst Bacteriol 47, 577-583.

Kim, M. K., Schubert, K., Im, W. T., Kim, K. H., Lee, S. T. \& Overmann, J. (2007). Sphingomonas kaistensis sp. nov., a novel alphaproteobacterium containing pufLM genes. Int J Syst Evol Microbiol 57, 1527-1534.

Kumar, S., Tamura, K. \& Nei, M. (2004). MEGA 3: integrated software for molecular evolutionary genetics analysis and sequence alignment. Brief Bioinform 5, 150-163.

Lee, J. S., Shin, Y. K., Yoon, J. H., Takeuchi, M., Pyun, Y. R. \& Park, Y. H. (2001). Sphingomonas aquatilis sp. nov., Sphingomonas koreensis sp. nov., and Sphingomonas taejonensis sp. nov., yellow-pigmented bacteria isolated from natural mineral water. Int J Syst Evol Microbiol 51, 1491-1498.

Marmur, J. \& Doty, P. (1962). Determination of the base composition of deoxyribonucleic acid from thermal denaturation temperature. J Mol Biol 5, 109-118.

Ohta, H., Hattori, R., Ushiba, Y., Mitsui, H., Ito, M., Watanabe, H., Tonosaki, A. \& Hattori, T. (2004). Sphingomonas oligophenolica sp. nov., a halo- and organo-sensitive oligotrophic bacterium from paddy soil that degrades phenolic acids at low concentrations. Int J Syst Evol Microbiol 54, 2185-2190.

Olsen, G. J., Matsuda, H., Hagstrom, R. \& Overbeek, R. (1994). fastDNAml: A tool for construction of phylogenetic trees of DNA sequences using maximum likelihood. Comput Appl Biosci 10, 4148.

Reddy, G. S. \& Garcia-Pichel, F. (2007). Sphingomonas mucosissima sp. nov. and Sphingomonas desiccabilis sp. nov., from biological soil crusts in the Colorado Plateau, USA. Int J Syst Evol Microbiol 57, 1028-1034.

Romanenko, L. A., Uchino, M., Frolova, G. M., Tanaka, N., Kalinovskaya, N. I., Latyshev, N. \& Mikhailov, V. V. (2007). Sphingomonas molluscorum sp. nov., a novel marine isolate with antimicrobial activity. Int J Syst Evol Microbiol 57, 358-363.

Ross, H. N. M., Grant, W. D. \& Harris, J. E. (1985). Lipids in archaebacterial taxonomy. In Chemical Methods in Bacterial Systematics, pp. 289-300. Edited by M. Goodfellow \& D. E. Minnikin. London: Academic Press.

Sait, M., Hugenholtz, P. \& Janssen, P. H. (2002). Cultivation of globally distributed soil bacteria from phylogenetic lineages previously only detected in cultivation-independent surveys. Environ Microbiol 4, 654-666.

Takeuchi, M., Sakane, T., Yanagi, M., Yamasato, K., Hamana, K. \& Yokota, A. (1995). Taxonomic study of bacteria isolated from plants: proposal of Sphingomonas rosa sp. nov., Sphingomonas pruni sp. nov., Sphingomonas asaccharolytica sp. nov., and Sphingomonas mali sp. nov. Int J Syst Bacteriol 45, 334-341. 
Takeuchi, M., Hamana, K. \& Hiraishi, A. (2001). Proposal of the genus Sphingomonas sensu stricto and three new genera, Sphingobium, Novosphingobium and Sphingopyxis, on the basis of phylogenetic and chemotaxonomic analyses. Int J Syst Evol Microbiol 51, 1405-1417.

Thompson, J. D., Gibson, T. J., Plewniak, F., Jeanmougin, F. \& Higgins, D. G. (1997). The CLUSTAL_X windows interface: flexible strategies for multiple sequence alignment aided by quality analysis tools. Nucleic Acids Res 25, 4876-4882.

Worliczek, H. L., Kämpfer, P., Rosengarten, R., Tindall, B. J. \& Busse, H. J. (2007). Polar lipid and fatty acid profiles-re-vitalizing old approaches as a modern tool for the classification of mycoplasmas? Syst Appl Microbiol 30, 355-370.

Wu, C., Lu, X., Qin, M. \& Ruan, J. (1989). Analysis of menaquinone compound in microbial cells by HPLC. Microbiology (English translation of Mikrobiologiia) 16, 176-178.

Xie, C. H. \& Yokota, A. (2006). Sphingomonas azotifigens sp. nov., a nitrogen-fixing bacterium isolated from the roots of Oryza sativa. Int J Syst Evol Microbiol 56, 889-893.

Xin, H., Itoh, T., Zhou, P., Suzuki, K. \& Nakase, T. (2001). Natronobacterium nitratireducens sp. nov., a haloalkaliphilic archaeon isolated from a soda lake in China. Int J Syst Evol Microbiol 51, 18251829.

Yabuuchi, E., Yano, I., Oyaizu, H., Hashimoto, Y., Ezaki, T. \& Yamamoto, H. (1990). Proposals of Sphingomonas paucimobilis gen. nov. and comb. nov., Sphingomonas parapaucimobilis sp. nov., Sphingomonas yanoikuyae sp. nov., Sphingomonas adhaesiva sp. nov., Sphingomonas capsulata comb. nov., and two genospecies of the genus Sphingomonas. Microbiol Immunol 34, 99-119.

Yabuuchi, E., Kosako, Y., Fujiwara, N., Naka, T., Matsunaga, I., Ogura, H. \& Kobayashi, K. (2002). Emendation of the genus Sphingomonas Yabuuchi et al. 1990 and junior objective synonymy of the species of three genera, Sphingobium, Novosphingobium and Sphingopyxis, in conjunction with Blastomonas ursincola. Int J Syst Evol Microbiol 52, 1485-1496.

Yoon, J. H., Lee, M. H., Kang, S. J., Lee, S. Y. \& Oh, T. K. (2006). Sphingomonas dokdonensis sp. nov., isolated from soil. Int J Syst Evol Microbiol 56, 2165-2169.

Zhang, D., Yang, H., Zhang, W., Huang, Z. \& Liu, S. J. (2003). Rhodocista pekingensis sp. nov., a cyst-forming phototrophic bacterium from a municipal wastewater treatment plant. Int J Syst Evol Microbiol 53, 1111-1114. 